\title{
An Expanded Look at Employment
}

\author{
Kevin L. Kliesen
}

$\mathrm{O}$ $\mathrm{n}$ the first Friday of each month, the Bureau of Labor Statistics (BLS) releases its closely scrutinized monthly employment report. Data in this report are derived from two surveys: the Census Bureau's Current Population Survey, also known as the household survey; and the Current Employment Statistics survey (CES), which is a survey of nonagricultural business establishments (including government offices). ${ }^{1}$

One of the limitations of the CES is that data for average weekly hours and average hourly earnings are reported for only a subset of workers: currently, production, construction, and nonsupervisory workers. The production classification is used in the goods-producing sector, while the non-supervisory classification is used in the service-producing industries. Workers in these two categories account for about 80 percent of private nonagricultural employment.

According to the BLS, this classification system has become increasingly archaic. Many employers do not classify workers by these two categories, which has led to relatively high nonresponse rates. ${ }^{2}$ Looking to the future, the BLS began publishing an experimental series in April 2006 that measures average hourly earnings and average weekly hours of all nonfarm private-sector employees. The BLS also began publishing an experimental gross monthly earnings series that includes both wages and salaries and benefits such as bonuses, stock options, and employer contributions to 401(k) plans. The existing BLS average hourly earnings series excludes these kinds of benefits.

These experimental data are relatively new and so are not seasonally adjusted, as the existing data are. Moreover, these data are published with a two-month lag. (For example, if the official data are available for January 2008, the experimental series are available only through November 2007.) The experimental allemployee series for hours and earnings will become the official data in February 2010, with the release of the January 2010 data. At that time the BLS believes that it will have had enough time to reliably estimate monthly seasonal factors.

These experimental hours and earnings series have potentially significant implications for measures of nonfarm business productivity and personal income. For example, the BLS uses the CESbased series of hours paid of production and non-supervisory workers as the key input into its measure of hours worked (the denominator in output per hour). ${ }^{3}$ If the existing CES series is not reporting a complete picture of hours worked, then measures of productivity will be affected.

The charts show the percentage difference between the existing and experimental series for average hourly earnings and average weekly hours (not seasonally adjusted): The experimental measure of hours is on average between 1 and 3 percent higher than the existing measure. The experimental measure of average hourly earnings is also consistently higher than the existing measure: As of November 2007, this difference was about 19.5 percent ( $\$ 21.12$ versus $\$ 17.63$, respectively). These charts seem to imply that workers not currently classified as production or non-supervisory employees tend to work longer hours and earn more per hour.

\footnotetext{
${ }^{1}$ For more detail, see the BLS's Handbook of Methods; www.bls.gov/opub/hom/ home.htm.

2 "CES Program: Changes Planned for Hours and Earnings Series." Monthly Labor Review, October 2003, pp. 38-39; www.bls.gov/opub/mlr/2003/10/ressum1.pdf.

3 See Parker, Robert P. "New Monthly Hours and Earnings Measures from the Bureau of Labor Statistics' Current Employment Statistics Program.” Business Economics, April 2007, pp. 69-74.
}

\section{Experimental Series Relative to Existing BLS Series}

\section{Average Weekly Hours}

Percentage Difference

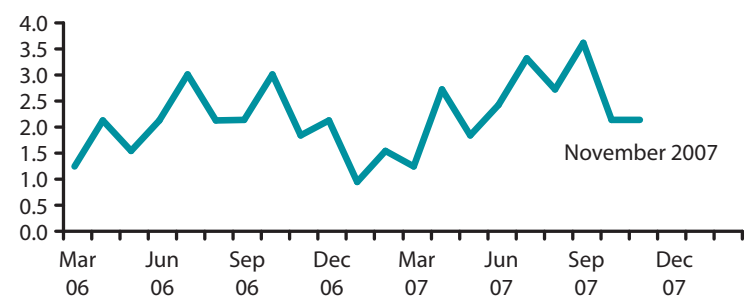

\section{Average Hourly Earnings}

Percentage Difference

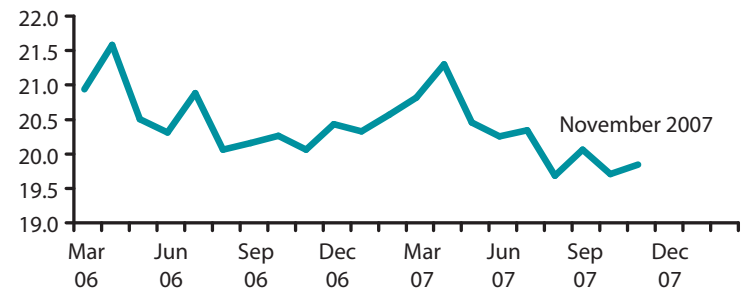

Views expressed do not necessarily reflect official positions of the Federal Reserve System. 